\author{
Anna Małgorzata Kamińska \\ Zakład Bibliotekoznawstwa \\ Instytut Bibliotekoznawstwa i Informacji Naukowej \\ Uniwersytet Śląski w Katowicach \\ e-mail: anna.kaminska@us.edu.pl
}

(D) https://orcid.org/0000-0001-5411-5426

\title{
Hello world : jak być człowiekiem \\ w epoce maszyn / Hannah Fry, przekład Sebastian Musielak. - Kraków : Wydawnictwo Literackie, cop. 2019. - 307, [4] s. : il. ; 21 cm. - ISBN 978-83-080-6819-9
}

Zagadnienie sztucznej inteligencji (SI) to obecnie jedna z najbardziej popularnych i najszybciej rozwijających się dziedzin badań transdyscyplinarnych. SI, zaprojektowanej do wykonywania konkretnych zadań z wykorzystaniem algorytmów, powierzane są coraz bardziej złożone zagadnienia, jak analiza wyników badań medycznych czy sterowanie autonomicznymi pojazdami.

Brytyjska matematyczka Hannah Fry w swojej książce w klarowny sposób wyjaśnia, czym są algorytmy, jak działają i jaki mają wpływ na ludzkie zachowania. Nie jest to lektura przesycona szczegółami technicznymi, a opisy działania poszczególnych algorytmów przeplatane są przykładami zaskakujących, a czasem przerażających sytuacji i zachowań, które te narzędzia do wspomagania podejmowania decyzji mogą wywołać.

Autorka opisuje rozmaite algorytmy, które są nam pomocne w życiu. Algorytmy, czyli ciągi instrukcji logicznych, „mówią” od początku do końca, jak wykonać określone zadanie: „niewidzialne fragmenty kodu tworzące konstrukcję i mechanikę współczesnej ery maszyn, dały światu wszystko - od subskrypcji kanałów informacyjnych w mediach społecznościowych, przez wyszukiwarki i nawigację satelitarną, aż po 
systemy rekomendacji utworów muzycznych - i stanowią część naszej nowoczesnej infrastruktury na równi $\mathrm{z}$ mostami, budynkami i fabrykami" (s. 12-13). Algorytmy, o których mowa w książce, to niemal zawsze obiekty matematyczne, korzystające z równań, arytmetyki, analizy, algebry, rachunku prawdopodobieństwa i logiki, przetwarzające ciąg operacji matematycznych na kod maszynowy. Liczba istniejących dziś algorytmów jest trudna do oszacowania. Nie znamy metody, która pozwoliłaby na ich jednoznaczne pogrupowanie. Autorka podzieliła zadania wykonywane przez algorytmy w świecie rzeczywistym na cztery główne grupy:

- priorytetyzacja - tworzenie uporządkowanej listy;

- klasyfikacja - wybór kategorii;

- asocjacja - wyszukiwanie linków;

- filtrowanie - wyróżnianie tego, co ważne (s. 19-21).

Większość algorytmów jest budowana tak, by łączyć kilka wymienionych wcześniej funkcji. Ze względu na sposób podejścia algorytmów do treści H. Fry wyróżniła dwa wzorce:

- algorytmy regułowe - pracujące na regułach, które są możliwe do zinterpretowania przez człowieka;

- algorytmy uczenia maszynowego - sposobem uczenia się tych algorytmów jest inspiracja sposobem uczenia się istot żywych (s. 21-23).

Algorytmy regułowe operują na zbiorze utworzonych wcześniej regul, zdefiniowanych przez eksperta dziedzinowego bądź określonych w procesie automatycznego uczenia. Algorytmy uczenia maszynowego zawierają się $\mathrm{W}$ szerszym pojęciu sztucznej inteligencji. Wspomagają rozwiązywanie zadań, przy których nie sprawdzają się napisane przez człowieka listy instrukcji. Zdarza się, że ścieżka prowadząca do rozwiązania nie ma dla ludzi sensu i jest niezrozumiałym wyborem maszyny. Wadą tych algorytmów, w przeciwieństwie do algorytmów regułowych, jest brak możliwości interpretacji zbioru danych, będącego zapisem wiedzy zdobytej w procesie uczenia.

W kolejnych rozdziałach autorka analizuje ukryte możliwości algorytmów. Opisuje wykorzystywanie algorytmów w różnych zawodach, związanych np. z wymiarem sprawiedliwości, medycyną, przemysłem samochodowym i sztuką. Wyjaśnia, w jaki sposób algorytmy są coraz częściej pomocne w podejmowaniu decyzji przez ludzi. Algorytmy używane przez lekarzy, służące do podważania diagnoz. Algorytmy stosowane w polityce, wpływające na poglądy wyborców i wyniki wyborów. Algorytmy wykorzystywane przez policję w celu ustalenia potencjalnych podejrzanych; stawiające człowieka przed wyborem: czy chronić ofiary przestępstw czy respektować uniwersalne prawo domniemywania nie- 
winności. Algorytmy dotyczące opinii w zakresie właściwego działania wymiaru sprawiedliwości; używane przez sędziów do formułowania orzeczeń i podejmowania decyzji. Stosowane w przemyśle samochodowym, w produkcji samochodów autonomicznych algorytmy, które jeszcze nie będąc $\mathrm{w}$ publicznym użyciu, już zdążyły podzielić opinię publiczną w kwestii: czy algorytm powinien podejmować decyzje etyczne, od których będzie zależało życie nasze i innych ludzi.

Gdziekolwiek spojrzeć - wymiar sprawiedliwości, służba zdrowia, policja, nawet handel w Internecie - borykamy się z naruszeniami prywatności, z uprzedzeniami, błędami, brakiem odpowiedzialności i przejrzystości; niełatwo przewidzieć, kiedy to się skończy. Już samo pojawienie się algorytmów zachwiało poczuciem uczciwości, które dotyka istoty naszego człowieczeństwa i każe nam zadawać sobie pytania o to, jak ma wyglądać nasze społeczeństwo i jak skutecznie sobie radzić z nadciągającą erą wszechwładzy beznamiętnej techniki (s. 255).

Autorka stawia pytania o zachowania etyczne związane $\mathrm{z}$ wykorzystaniem algorytmów, a także o poniesione nakłady finansowe i czasochłonność poszczególnych procesów. Nie udziela jednoznacznych odpowiedzi na zawarte w tytule książki pytanie: jak być człowiekiem w epoce maszyn? Opisuje za to relacje między ludźmi i już istniejącymi algorytmami. Takimi, które poprawiają nasze błędy i wspomagają rozwiązywanie problemów. Podkreśla, że żaden przedmiot czy algorytm nie są złe ani dobre same w sobie, a decyduje o tym sposób ich wykorzystania. Algorytmy powinny być postrzegane jako pomoc dla ludzi $\mathrm{w}$ podejmowaniu decyzji, a nie jako nieomylny autorytet. W książce wielokrotnie pojawia się pytanie o to, kiedy powinniśmy bardziej zaufać maszynie, a kiedy własnemu osądowi, i jak rozwój techniki zmienia nasze poglądy i oczekiwania wobec maszyn. Autorka podkreśla komplementarność ludzi i algorytmów. Ludzie są dobrzy w zauważaniu niuansów i subtelności, analizowaniu treści, czerpaniu z doświadczeń i rozróżnianiu wzorców. Są empatyczni, mają świadomość swojego otoczenia i własnych umiejętności. Wykorzystując swój potencjał, sprawiają, że algorytmy stają się doskonalsze.

Niewykluczone, że najlepszym rozwiązaniem będzie konstruowanie takich algorytmów, które będzie można sprawdzać na każdym etapie funkcjonowania. Wyobraźmy sobie, że będziemy je budować raczej po to, żeby wspierały ludzi w podejmowaniu decyzji, 
a nie po to, żeby nas instruowały, co powinniśmy robić. Żeby potrafiły pokazać nam ścieżkę prowadzącą do każdej swojej decyzji, a nie tylko informowały nas o wynikach obliczeń. W moim odczuciu najlepsze algorytmy to takie, które uwzględniają człowieka na każdym etapie swojego działania. Takie, które wiedzą, że mamy zły nawyk traktowania maszyn jako nieomylne, i takie, które są świadome własnych wad, więc z dumą prezentują nam swoją niedoskonałość (s. 258).

Tekst $w$ wersji poprawionej wptynąt do redakcji 12 marca 2019 r. 